University of St. Thomas, Minnesota

UST Research Online

Operations and Supply Chain Management

Faculty Publications

2005

Operational, economic and mission elements in not-for-profit organizations: A case of the Chicago symphony orchestra

John R. Olson

University of St. Thomas, Minnesota, jrolson2@stthomas.edu

Follow this and additional works at: https://ir.stthomas.edu/ocbopmtpub

Part of the Business Administration, Management, and Operations Commons, Management Sciences and Quantitative Methods Commons, and the Operations and Supply Chain Management Commons

This Article is brought to you for free and open access by the Operations and Supply Chain Management at UST Research Online. It has been accepted for inclusion in Operations and Supply Chain Management Faculty Publications by an authorized administrator of UST Research Online. For more information, please contact asle4660@stthomas.edu. 


\title{
Operational, economic and mission elements in not-for-profit organizations: the case of the Chicago Symphony Orchestra
}

\author{
John R. Olson ${ }^{\mathrm{a}, *}$, James A. Belohlav ${ }^{\mathrm{b}, * *}$, Kenneth K. Boyer ${ }^{\mathrm{c}, 1}$ \\ ${ }^{\mathrm{a}}$ Management Department, College of Business, University of St. Thomas, \\ 1000 Lasalle Avenue, Minneapolis, MN 55403, USA \\ ${ }^{\mathrm{b}}$ Management Department, Kellstadt Graduate School of Commerce, DePaul University, \\ 1 E. Jackson Blvd., Chicago, IL 60604-2287, USA \\ ${ }^{c}$ Department of Marketing and Supply Chain Management, The Eli Broad Graduate School of Management, \\ Michigan State University, N370 North Business Complex, East Lansing, MI 48824-1122, USA
}

Received 30 October 2003; received in revised form 15 May 2004; accepted 15 July 2004 Available online 5 November 2004

\begin{abstract}
The term not-for-profit often brings to mind the idea of an altruistic organization serving society. The reality is that the notfor-profit is a far more complex organization that is responsible to diverse groups of stakeholders. Unlike for-profit organizations, not-for-profit (NFP) organizations have to focus on dual, and often conflicting, goals relating to fulfilling their overall mission while also generating enough revenue to maintain their operating structures. In order to better understand the nature of the dual orientation of the NFP organization, the behavior of Chicago Symphony Orchestra (CSO) patrons using the CSO website is viewed. Specifically, this study examines data for individuals purchasing CSO concert tickets on-line during an 8-month period in 2000-2001. MANOVA and ANOVA statistical procedures are used to analyze the effects of both the economic and mission related orientations operationalized through the e-service encounter. Further, we view data from the online ticketing function relative to the labor costs of the Chicago Symphony Orchestra.
\end{abstract}

(C) 2004 Elsevier B.V. All rights reserved.

Keywords: Non-profit organizations; Not-for-profit organizations; Symphony orchestra; Operations strategy; Mission based management; eService

* Corresponding author. Tel.: +1 6519625544 .

E-mail addresses: jrolson2@stthomas.edu (J.R. Olson), jbelohla@depaul.edu (J.A. Belohlav), boyerk@msu.edu

(K.K. Boyer).

** Co-corresponding author. Tel.: +1 312362 6061; fax: +1 3123626973 .

${ }^{1}$ Tel.: +1 517353 6381; fax: +1 5174321112 .

\section{Introduction}

During the past three decades, economic, social and political forces have combined to shape the destinies of organizations across the globe. Most notable during 
this time period, though, has been the rapid and continuing growth of the not-for-profit (also referred to as nonprofit) organizations. Commenting on the development of the not-for-profit sector Salamon (1994) observes, "The scope and scale of this phenomenon are immense. Indeed, we are in the midst of a global 'associational revolution' that may prove to be as significant to the latter twentieth century as the rise of the nation-state was to the latter nineteenth" (p. 109). Only 20 years ago, the not-forprofit organization was considered to be, at best, a marginal contributor wherever it existed. Today these same organizations have become significant, if not indispensable, elements within the economies of countries throughout the world.

Even though the term not-for-profit organization is often used as if it were a uniform descriptor, in fact, it is a complex, diverse organizational form. The literature from several disciplines illustrates its multidimensional character. Essentially the not-forprofit organization consists of several fundamental aspects, which include: an economic aspect, a mission-related aspect and an operational aspect. How these fundamental aspects interconnect is what has created the distinctive nature of the not-for-profit organization. The focus of the present research is to assess how well the economic and mission aspects of the CSO are operationalized through the e-service encounter. Specifically, the study examines the overall satisfaction of CSO patrons who purchased concert tickets on-line during the 2000-2001 concert season.

\section{The Chicago Symphony Orchestra}

The Chicago Symphony Orchestra (CSO) is a wellestablished and successful not-for-profit organization. Founded in 1891, the CSO is recognized as a premier symphony orchestra. Because of its success in carrying out its mission, the artistic, musical side of the CSO is well known throughout the world. In fact, the Chicago Symphony derives more than $50 \%$ of their total revenues from sales of tickets to performances and merchandise. The mission and economic accomplishments have had a significant impact on the success of the organization. However, the operational side of the CSO, while less publicized, provides the critical linkage to both the mission and economic aspects of the organization through its scheduling, publicity, venue operations and ticket sales for over 200 annual events. In a typical year, more than $95 \%$ of all available seats are sold.

In an effort to expand their market base, improve customer service, and reduce costs, the CSO considered using the Internet. Even though the Internet was still a relatively new technology in 1998 they decided to proceed cautiously because they were aware of the significant benefits that were accruing to organizations that had successfully automated their ticketing process by means of the Internet (Boyer, 2001). Hundreds of companies have provided online access to their ticketing services including, all major professional sports teams, ticketmaster.com and many other entertainment venues.

After much deliberation, the CSO began selling tickets on-line in 1998. Their first venture onto the Internet was just an informational website in which patrons could access concert information and send an email with concert and ticket price information to the $\mathrm{CSO}$ in order to purchase tickets. When their first website was installed, the CSO employed several individuals within their ticket call center. Since their initial attempt, the CSO has continued to enhance its website to provide greater access to tickets and improve functionality. Today the CSO sells approximately $50 \%$ of total sales over the Internet and expects this number to grow further via successive improvements. The CSO ticket sales over the Internet grew eight-fold over the period of 1999-2001. The ultimate goal of the CSO is to move their entire inventory of tickets on-line in future years.

\section{Review of not-for-profit orientations}

The CSO, like all not-for-profit organizations, has been subject to various environmental forces that have affected its growth and development. Section 3 examines the economic, the mission, and the operational factors and their role in shaping the notfor-profit operating environment. The e-service encounter is used as the means to examine how these factors interrelate within an overall organizational operating context. 


\subsection{Economic orientation}

The relatively recent expansion of the nonprofit sector organizations has come as a result of the confluence of several basic but interrelated socioeconomic factors, those being: large scale growth, governmental expansion, general levels of prosperity, technological changes and demographic trends (Anheier and Ben-Ner, 1997). When taken together, these factors provided the "critical mass" necessary to facilitate the growth and development of the not-forprofit organization within a supply and demand context. Essentially, the not-for-profit organization's growth has come from the existence of unsatisfied demand (Ben-Ner and van Hoomissen, 1991). That is, the not-for-profit has prospered because of the inability or unwillingness of the for-profit (also referred to as private sector) organizations and the failure of the government to recognize the needs that were present for particular types of goods or services.

How important have the not-for-profit organizations become? In examining the development within eight major countries, the nonprofit sector was found on the average to account for, " 3.3 percent of total employment - a share not to different from those of the banking and transportation industries" (Anheier and Ben-Ner, 1997, p. 336). As a result of their growth, the not-for-profits can no longer be viewed as "invisible" institutions but rather they have evolved into influential economic forces within both industrial and developing countries. In fact, this economic sector was responsible for the generation of $13 \%$ of all net new jobs in the United States and some industrial European countries during the decade of the 1980s (Anheier and Rudney, 1998). The economic dimension of the not-for-profit organization resembles that of the for-profit organization, in that, it is concerned with revenue generation, cost control, and job creation. While their role as an economic force has allowed not-for-profit organizations to climb to a position of consequence within many countries, their specific organizational mission has been considered to be of paramount importance.

\subsection{Mission orientation}

Rather than the simple depiction that some individuals have of the not-for-profit organization, the CSO and all not-for-profits have grown into complex entities that continue to change along with the socio-economic factors that were the impetus for their development. A key facet among all of the notfor-profit organizations, regardless of their size or complexity, is their mission. Quarter and Richmond (2001) comment, "nonprofits are organized around a social mission, which some would argue is their defining criterion." The mission is the reason for the existence of the not-for-profit both from a social and a legal point of view. It is also the primary differentiator from the for-profit organization, whose basic motive is primarily economic.

The mission can be seen as a directive that goes beyond the immediate operating environment of the particular not-for-profit organization to link with the community and society at large. The mission of the CSO provides an illustration of the preceding commentary. Its mission is:

The central mission of the Chicago Symphony Orchestra Association is to present classical music through the Chicago Symphony Orchestra to Chicago, national and international audiences. To accomplish the mission the association will: sustain the very highest artistic quality in all of its programs, develop and sustain a strong diverse audience base, and increase the awareness and enjoyment of music in the life of the greater Chicago community.

The mission emphasizes musical enjoyment, education, and serves as an exchange for music lovers of all ages and cultural backgrounds. For the not-forprofit organization, many aspects of the mission are focused toward a greater societal value which extends beyond the pure economic reasons of the for-profit organization.

Even though the mission is the defining characteristic of the not-for-profit organization, there are many different missions and many different means of accomplishing them. As a consequence, there are a wide variety of not-for-profit organizations that exist and varying views of what are not-for-profits. Salamon (1996) supports the preceding observation by noting that the not-for-profits no longer exist as a uniform classification, except possibly as a legal classification, and that the line differentiating them from the for-profit organization is becoming quite blurred. 


\subsection{Operational orientation}

New relationships are being formed as for-profit organizations are moving into areas that were once solely the province of the not-for-profit sector thereby creating escalating levels of competition. Even established relationships can change sometimes literally overnight. "Reductions in funding from grants and contributions and increased demands from the public for efficient use of remaining dollars have pressured nonprofits to improve accountability" (Durst and Newell, 2001, p. 444). For example, the National Endowment for the Arts (NEA) in 1996 reduced their overall appropriations from over 160 million to less than 80 million (NEA, 2004). With changing socioeconomic forces and institutional relationships, the not-for-profits interact within increasingly complex operating environments. Many not-for-profits, as a consequence, are being confronted by conflicting goals to the point where some organizations have even relinquished their not-forprofit status (Ryan, 1999). Thus, how not-for-profit organizations structure their operational activities becomes a significant element in determining how well they can carry out their mission or perhaps whether they can carry out their mission at all.

One of the ways that not-for-profits are reacting to current pressures is by adopting the same techniques that for-profit businesses use in hopes of increasing their own effectiveness in terms of operational performance, expense reduction, and revenue generation. In an effort to improve operational performance, a number of directions are being presented for non-forprofit organizations, including information systems and the Internet (Burt and Taylor, 2000; Saidel and Cour, 2003), "reinventing" operations (Durst and Newell, 2001) and enterprise schemes (Bryson et al., 2001). The success in adopting for-profit practices has been mixed, though, leading Rojas (2000) to remark, "nonprofits are haphazardly implementing management practices of the for-profit sector" (p. 97).

The experience of symphony orchestras in adapting information technology into their operational processes aptly depicts why there is the perception of haphazard implementation. The popular press has widely publicized the fact that the symphony audiences have been getting older. The "graying" of the symphony audience has forced many of the world renowned orchestras to look to new ways to expand the size of their market (Vence, 2003). One popular response has been to offer patrons the option to purchase tickets on-line. For example in 2001, The Boston Symphony Orchestra had to revamp their website in an attempt to get more patrons to buy on-line because early versions did not reach their target audience (Colkin, 2001). The unanticipated consequence was the level of the challenge in attracting existing patrons to their website to purchase tickets. The Chicago Symphony Orchestra experience also followed a similar pattern. It introduced Internet ticketing in 1999 and proceeded to sell approximately $0.5 \%$ of total sales over the Internet in its first year (Boyer, 2001). Because they lacked experience and did not fully understand the operational issues confronting them, the CSO struggled with the development of an effective website. Their initial response was a reaction to customer demands and competitive pressures rather than as a well thought-out operational strategy (Boyer, 2001).

\subsection{Relationship among orientations-the not-for- profit e-service encounter}

Having to implement dual economic and mission orientations within their organization creates a paradoxical situation that has been both a boon and a bane for the not-for-profit organization. The dual economic and mission orientations have been an engine that has led to the growth of the not-for-profit. Within many arenas, though, it also has put many notfor-profit organizations into direct competition with for-profit business enterprises, which has both created functional difficulties for the not-for-profit and uncovered philosophical differences in reconciling their mission related goals and economic goals.

The operational dimension provides the missing piece of the puzzle in the not-for-profit literature. It is the integrating mechanism that can ultimately influence success not only in the economic aspects of the not-for-profit organization but also the mission aspects as well. The success of this integration is seen most clearly during the service encounter. In its simplest terms, the service encounter is the interaction of external constituencies (patrons, customers, clients, etc.) with the operational structure and processes of an organization. "It is the context in which the organization provides the customer with what is 
presumably of value" (Mechling and Little, 2000, p. 65). In a successful service encounter, the operational structure and processes should reflect the economic and mission aspects of the organization in a manner that is consistent with the patron's expectations.

The concept of a successful service encounter has been a topic that has been studied from the perspective of several functional disciplines which include operations management, marketing and information systems. In particular, SERVQUAL (Zeithaml et al., 1988) identifies several key elements that are related to a successful service encounter. A key aspect within the SERVQUAL literature focuses on the relationship of the performance-expectations gap to the overall improvement of service encounters. Increasingly, service encounters are taking place over the Internet and have come to be referred to as e-service encounters. Unlike the traditional service encounter, though, the e-service encounter introduces different qualities to the exchange that is taking place. The eservice encounter is distinctive because of the manner in which the service is delivered. That is, a primary difference between a traditional service encounter and e-service encounter is the lack of human interaction during the e-service encounter.

The information technology component of the eservice encounter presents added dimensions that rely on the capabilities of technology to make the e-service encounter successful. Zeithaml et al. (2000) present several of these dimensions in a conceptual framework that outlines e-service quality, including: website related items such as ease of navigation and use, operational components including order accuracy and fulfillment, in addition to traditional service encounter items such as timeliness. A crucial measurement within the e-service encounter is user satisfaction. Several studies demonstrate user satisfaction as a combination of website factors (information accuracy, navigation ease, etc.), and behavioral intentions toward the information technology (ease of use, perceived usefulness, etc.) (Devaraj et al., 2002; Reimenschneider et al., 2003; Torkzadeh and Dhillon, 2002; Davis et al., 1989). The research has clearly pointed out that one of the sources of satisfaction comes from the ability to find information about the intended products or services (Froehle et al., 2000).

The loss of human interaction potentially leads to an overall reduction in the consumer's ability to gather information, which in turn can reduce the ability of the consumer to make an informed decision. In one of the few articles that solely examines e-services, the authors (Iqbal et al., 2003) examine the differences between on-line consumers and off-line consumers. In this study, the findings that are of particular interest identify that on-line customers value the availability of real time information (timeliness and quality), and the ability to do research and analysis (R\&A) even more so than customers who do not purchase on-line. The end result of this access to additional information is that it provides consumers with enough data to make informed decisions. Further, retention has been found to be higher for shoppers in more transparent informational environments (Lynch and Ariely, 2000).

Another significant aspect of the e-service encounter is that transactional information can be seamlessly integrated back into the organization. Lynch and Ariely (2000) have reported that web integrated sales systems have an impact on transaction costs of the organization. For example, Office Depot has reported that savings associated with transaction costs for online purchases to be approximately $1 \%$ of sales (Boyer and Olson, 2002).

In an effort to assess the effectiveness of achieving the dual orientation of a not-for-profit organization, often the supposition is made that if the for-profit or economic aspects are running efficiently then it is also assumed that the mission is also being met. However, the significant dilemma confronting the not-for-profit is that one set of stakeholders is concerned with whether the money is being used efficiently and another set of stakeholders is concerned with whether the mission is being accomplished effectively. The real test is even when not-for-profits are able to improve economic performance are they assessing whether the mission is being met?

\section{Research questions}

Because of its rapid growth, an in-depth examination of the managerial and operational aspects of notfor-profit institutions has tended to lag that of the forprofit organizations. Given the preceding discussion, the research question posed in this study is, "How do the economic and mission orientations of the CSO influence its performance?" To examine this question, 
the nature of the service encounter of CSO patrons will be examined.

\subsection{Measuring economic and mission orientation through the e-service encounter}

One of the significant ways in which the economic and mission aspects of the CSO are operationalized is through its website. The CSO website has two primary functions: (1) the sale of concert seats and merchandise; and (2) the education of the public about the mission of the CSO. This study examined how patrons interacted with the CSO through their website.

\subsubsection{Economic orientation}

The economic orientation is related to the sale of concert seats on the website. Since the primary way in which patrons interact with the CSO website is through the purchase of concert seats on-line, the economic portion is assessed by examining usage patterns related to the various ordering tools. The ordering tools allow the customer to access information related to purchasing tickets on-line. Specifically the ordering tools allow patrons to view event descriptions and dates, choose their seats in the orchestra hall, and obtain e-mail notification of time of purchase. The seat selection tool is unique in that it allows patrons to actually see a digital image of their view in Orchestra Hall.

\subsubsection{Mission orientation}

Iqbal et al. (2003) have shown that the R\&A information in e-services was directly related to the purchase of goods and services. The R\&A component provide consumers with the additional information necessary to make informed choices. The educational tools portion of the website directly relates to the R\&A component present in Iqbal et al's study. That is, the mission related information on the CSO website includes information related to music history, CSO history, music clips, and other CSO related information. The ability to research this information provides patrons with the information necessary to make informed decisions relative to purchasing tickets.

\subsubsection{Service encounter}

A patron's e-service encounter will be a function of the website's attributes and their ability to satisfy their particular needs and requirements. The effectiveness of the delivery of economic and mission aspects of the CSO will be reflected by the website usage patterns of a patron. This study will examine how patron usage of specific parts of the website, ordering tools and educational tools, relates to their perceptions of their experience in their interaction with the CSO.

\subsection{Hypotheses}

Dees (1998) presents the idea that organizations exist as social enterprises that can be situated on a spectrum that encompasses both economic and mission related aspects. Thus, the framework of Dees would imply that in order for the not-for-profit organization to be successful attention would have to be focused on both orientations. If this framework is an accurate depiction, then not-for-profit organizations that are able to recognize and satisfy both dimensions would have the most satisfied consumer groups. To examine the existence of this relationship, the following hypothesis will be tested relative to the CSO:

$\mathbf{H}_{1}$. Holding all else constant, patrons will exhibit differences in overall satisfaction across the mission and economic dimensions of the CSO website.

In this study, satisfaction is measured in three key areas: a patron's perception of system effectiveness, a patron's beliefs about their interaction with the CSO website, and the personal strategy each patron uses while interacting with the CSO website. Several studies have indicated that these concepts are important to the overall e-service encounter. In particular, Zeithaml et al. (2000) indicate that these factors are important to the overall e-service encounter. To date no study has examined the relationship between these concepts and their overall impact on individuals. Specifically we seek to explore the following hypotheses:

$\mathbf{H}_{2 \mathbf{a}}$. Patrons using the whole CSO website perceive greater system effectiveness than do patrons using only portions of the CSO website.

$\mathbf{H}_{2 \mathbf{b}}$. Patrons using the whole CSO website perceive greater ease of interaction than do patrons using only portions of the CSO website. 


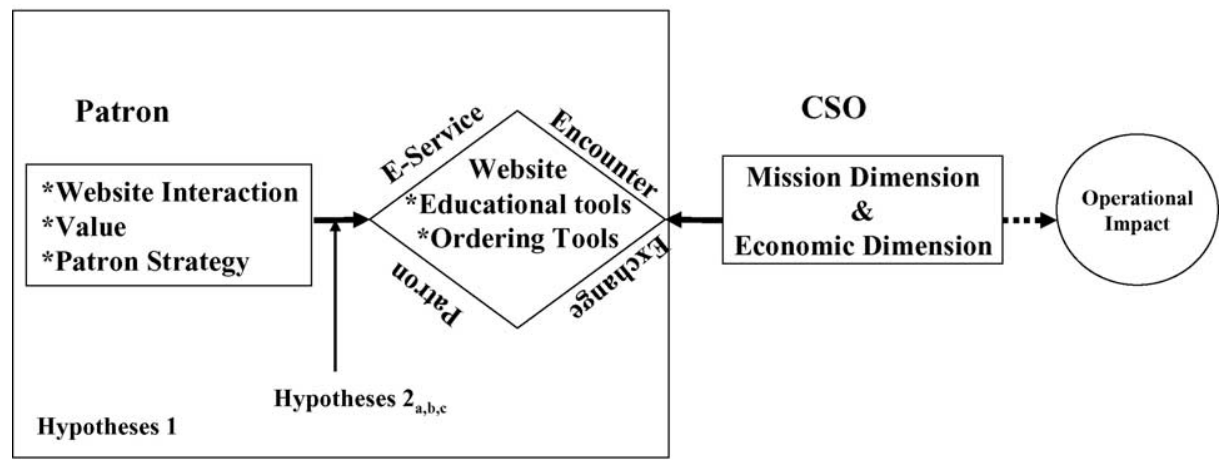

Fig. 1. E-service encounter exchange model for not-for-profit organizations.

$\mathbf{H}_{\mathbf{2 c}}$. Patrons using the whole CSO website better satisfy their personal strategy than do patrons using only portions of the CSO website.

Fig. 1 presents the overall research model presented in this paper. Hypothesis 1 examines the overall relationship between the two orientations and patron satisfaction. Hypotheses 2a-c examines the specific relationships through the e-service encounter. The dotted line between the CSO and organization performance indicates that this is not directly tested with the data collected, however the time-series CSO performance data is viewed later in the manuscript.

\section{Research methodology}

\subsection{Data collection}

\subsubsection{Sample}

The data in this study was collected from patrons of the CSO who had placed at least one order over the Internet during the past concert season. These orders were placed during the time period from September 2000 through April 2001. The initial database contained approximately 5100 individuals who had placed orders during the past concert season.

Based upon financial and other considerations, it was determined that the size of the sample should be about $10 \%$ of the total CSO Internet ticket purchasers from the previous concert season. The purchasing population was divided into two strata: frequent purchasers (tickets purchased two or more times) and single time purchasers. The final composition of the sample included all of the frequent purchasers (100\% sampling) along with a simple random sampling of patrons with a single Internet purchase during the past year. The final sample contained equal proportions of single Internet purchase patrons and frequent purchase patrons. It should be noted that a single Internet purchase could be one or more tickets.

\subsubsection{Survey instrument}

The final, pretested survey instrument consisted of several items that comprised the independent and dependent variables. To assess each of those key variables, several scales were used. Existing scales were drawn from several studies along with several new scales that were developed specifically for the CSO. Each scale item in the MANOVA represents a dependent variable in the analysis. A detailed discussion of the independent variables and dependent variables is provided in Sections 5.2.1 and 5.2.2, respectively. All of the items were measured using a 7point Likert type of scale. For all items, higher scores indicate higher levels of that item.

Each survey questionnaire had a cover letter attached to it stating the relationship of the researchers with the CSO as well as a letter from the CSO explaining the status of the researchers as being independent from the CSO. As an incentive to participate in the survey, the CSO offered a chance to win 1 of 25 pairs of tickets to the upcoming concert season.

\subsubsection{Survey response}

A total of 518 mail surveys were sent to the individuals that were selected to be in the study. 
Several steps were taken to maximize the response rate, including the inclusion of a business reply envelope, an incentive to complete the survey and the use of several follow-up letters. All of these steps have been found to be effective ways to increase response rates in other operations management research studies (Frohlich, 2002). The first reminder letter was mailed two weeks after the questionnaire was sent, reemphasizing the confidential nature and importance of filling out the survey. A second follow-up letter and another copy of the survey were mailed to individuals that had not filled out the original survey. A fairly small portion of responses was returned due to incorrect addresses. A total of 242 useable surveys were returned out of the original mailing of 518, representing an effective response rate of $46.7 \%$.

\subsection{Research design}

The CSO website is structured into two basic components: (1) access to purchasing tickets and other merchandise; and (2) access to community outreach and educational material related to the CSO Mission. Each of these foci became proxy measures in the study of the economic and mission orientations of the CSO. Independent variables were created to assess to what degree patrons of the $\mathrm{CSO}$ were using the purchasing or educational features on the website. The horizontal axis measured the economic orientation using a scale created from the collective set of ordering tools. The vertical axis measured the mission orientation using a scale created from the collective set of the educational tools. Fig. 1 presents the $2 \times 2$ factorial design used in this research study.

\subsubsection{Independent variables}

The independent variables were concerned with patron usage of various website features to purchase tickets and find information on the CSO website. Appendix A presents all of the scales and end item questions for each of the independent and dependent variables in the study. To assess the overall usage of economic elements of the CSO website, an ordering tool variable was created as an average score of all ordering tool features. A median split was then performed on the composite variable to generate the categories of high and low usage. The same process was repeated to generate the educational tool variable in the study. Patrons were then separated into four categories based on the two levels created for the independent variables.

The four separate categories created were Limited User, Functional User, Information Seekers, and Full Service Users (see Fig. 2). Limited User patrons are individuals who have very little interaction with the CSO other than the purchase of tickets. Functional User patrons are similar to the Limited User patrons, however, rather than logging on to the website to just purchase tickets without interaction with the website, these patrons utilize the ordering tool features to gain additional information about the CSO performances. These individuals less frequently use the educational tools available. Instead, they tend to use the website as a functional means to accomplish the task of buying tickets. Information Seekers are patrons who actively employ the educational aspects of the CSO website but only infrequently use the ordering tools that are available. While these patrons do purchase tickets, they tend to be more involved with many of the educational features of the website. Full Service Users are patrons who frequently use both the educational and informational tools when interacting with the CSO website.

\subsubsection{Dependent variables}

The dependent variables represent various patron relationships with the CSO. Specifically, the dependent variables reflect beliefs formed as a result of the

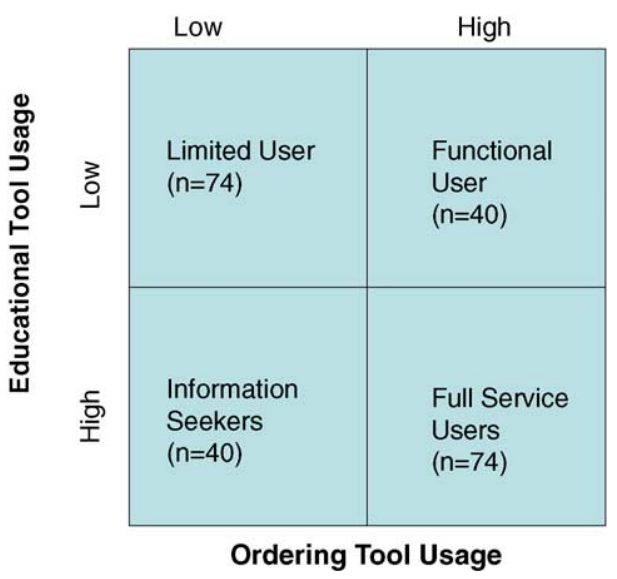

Fig. 2. The $2 \times 2$ factorial design for Chicago Symphony Orchestra data ordering tool usage. Chi-square indicates no statistical differences between cells 18 total incomplete responses in classification. 
interaction with the CSO and preexisting patron beliefs. Specifically the current study measures three key dependent variables. The dependent variables measured in this study are: System effectiveness, Website Interaction, and Patron Strategy. These variables are measured by a specific set of scales adopted from several previous studies as well as scales created specifically for the CSO data.

The dependent variables are an assessment of perceptions that patrons have of their interaction with the CSO website. The first dependent variable is a function of the patron's perception of utility of the website. Patron utility is measured by the system effectiveness dependent variable. The concept of utility in individual decision making has been developed in several disciplines. Much economics literature has focused on utility theory of households and consumers (Becker, 1965). Utility theory suggests that individuals will continue transactions as long as the benefits outweigh the costs (Ekelund and Ritenour, 1999). Further, the greater the perceived benefits the more likely it is that the individual will continue their transactions interaction with the host institution. Research suggests that the more a customer interacts with a website the higher perceived utility they receive from the website (Murphy et al., 2001).

Since we are assessing customers through on-line interactions, we assess value by the level of improvement patrons receive through on-line interactions relative to traditional methods. We measure this dependent variable using a single scale (five items), system effectiveness. This scale measures the items related to order fulfillment. The scale includes the measurement of time to place and order, delivery time, order documentation and accuracy and reliability of delivery. Previous studies have indicated that these are items that help measure the overall success of e-commerce systems (Torkzadeh and Dhillon, 2002; Zeithaml et al., 2000; Palvia and Palvia, 1999). Balasubramanian et al. (2003) indicate that this is a measure of perceived operational competence. The concept of operational competence can have a positive influence on the overall economic position of organizations (Konana and Balasubramanian (2004). Our expectation based on our hypotheses is that the Full Service Users will indicate they have the highest level of satisfaction, as measured by the system effectiveness variable.
The second dependent variable is labeled as website interaction. This variable measures how patron's interact with the website. There is a welldeveloped research literature relating to technology acceptance within organizations. The website interaction dependent variable consists of scales that were primarily derived from the technology acceptance model (Davis et al., 1989). Research has clearly shown that these scales are extremely important to the overall interaction of individuals and Internet based technology (Devaraj et al., 2002). The patron perceptions were measured using the scales of: perspective (four items), overall impression (two items), and ease of interaction (four items). The perspective and ease of interaction scales were adopted directly from the technology acceptance model. The first scale, perspective, measured several items focusing on general perceptions of the Internet and information technology. The second scale, ease of interaction, focused on measuring the general comfort level when undertaking Internet focused activities. The final scale, overall impression, is a specific scale that measures the patron's opinion of the CSO Internet website and if they will use the CSO website in the future. This factor has been an important finding to overall e-commerce satisfaction (Balasubramanian et al. 2003; Devaraj et al., 2002). In this study, the focus is on determining the how the measurements associated with the website interaction variable vary across each patron type.

The final dependent variable is labeled as patron strategy. The final dependent variable consists of preexisting patron characteristics that reflect individual preferences or perceived value required in the purchase of a product or service. The patron strategy perceptions were measured in three areas: cost (one item), convenience (three items), and transactional accuracy (four items). The first scale measured the patron's perceptions of cost. The second scale, convenience, measured various aspects comprising convenience including delivery speed and access to additional ticket information. Early research on ecommerce suggested that the primary motive for switching to e-commerce based systems was transaction costs and easy access to product availability (Lynch and Ariely, 2000). The final scale, transactional accuracy, measured the perceptions of several qualities of undertaking a transaction including, 
Table 1

Correlation matrix and descriptive data

\begin{tabular}{|c|c|c|c|c|c|c|c|c|c|c|c|c|}
\hline \multirow[t]{2}{*}{ Variable name } & \multicolumn{3}{|c|}{ Descriptive data } & \multicolumn{9}{|c|}{ Correlation matrix } \\
\hline & Mean & Standard deviation & $\alpha$ & A. & B. & C. & D. & E. & F. & G. & H. & I. \\
\hline \multicolumn{13}{|l|}{ Consumer dimensions } \\
\hline A. Ordering tool use & 6.22 & 0.63 & 0.78 & 1.00 & & & & & & & & \\
\hline B. Educational tool use & 4.79 & 1.26 & 0.87 & $0.39^{* *}$ & 1.00 & & & & & & & \\
\hline \multicolumn{13}{|l|}{ System efectiveness } \\
\hline C. System effectiveness & 5.29 & 0.95 & 0.86 & $0.20^{* *}$ & $0.25^{* *}$ & 1.00 & & & & & & \\
\hline \multicolumn{13}{|l|}{ Website interactions } \\
\hline D. Perspective & 5.47 & 1.01 & 0.77 & $0.30^{* *}$ & $0.22^{* *}$ & $0.27^{* *}$ & 1.00 & & & & & \\
\hline E. Overall impression & 6.22 & 0.97 & $0.57^{\mathrm{a}}$ & $0.24^{* *}$ & 0.02 & $0.33^{* *}$ & $0.42^{* *}$ & 1.00 & & & & \\
\hline F. Ease of interaction & 5.94 & 0.95 & 0.91 & 0.11 & 0.09 & $0.31^{* *}$ & $0.36^{* *}$ & $0.31^{* *}$ & 1.00 & & & \\
\hline \multicolumn{13}{|l|}{ Patron strategy } \\
\hline G. Cost & 3.38 & 2.02 & $N / A^{b}$ & 0.04 & $0.14^{*}$ & $0.19^{* *}$ & 0.07 & -0.04 & 0.05 & 1.00 & & \\
\hline H. Convenience & 6.23 & 0.87 & 0.72 & $0.14^{*}$ & -0.06 & $0.13^{*}$ & $0.15^{*}$ & $0.28^{* * *}$ & $0.14^{*}$ & -0.09 & 1.00 & \\
\hline I. Transaction accuracy & 5.23 & 1.34 & 0.78 & $0.19^{* *}$ & $0.19^{* *}$ & $0.31^{* *}$ & $0.23^{* *}$ & $0.16^{*}$ & $0.13^{*}$ & $0.27^{* * *}$ & $0.29^{* *}$ & 1.00 \\
\hline
\end{tabular}

ordering speed, order accuracy, customer assistance and order security.

Table 1 presents means, standard deviations and Cronbach's alpha values for each of the dependent variables and their related scales. Table 1 also presents the correlation matrix for all of the dependent and independent variables in the study.

\subsection{Data analysis and results}

The data were analyzed first using a MANOVA statistical procedure to test for significant main effects and interaction effects across each level of the independent variables. Independent ANOVA's were performed, where appropriate, to determine which dependent variables differed across the four categories in the research design. The MANOVA was used to analyze the data for two primary reasons: (1) MANOVA helps to protect against inflated Type I error due to multiple significantly correlated dependent variables; and (2) using a MANOVA analysis helps to examine the differences in the dependent variables at various levels of the independent variables (Tabachnick and Fidell, 2001). As a consequence, hypotheses at both the strategic level and the operational level can be tested. The overall MANOVA examines the strategic aspects of the study related to basic organizational orientations and determines if any differences exist across the various levels of our independent variables. The main and interaction effects specifically examine how the dependent variables vary. Fig. 3 provides a detailed overview of the analysis.

Significant correlations existed (Table 1) between many of the dependent variables such as attitude, overall impression, convenience, and transactional accuracy, indicating the appropriate use of the MANOVA technique. The determinant of the within cells correlation matrix was used to assess the potential impact of the correlations on the analysis. In this study, the determinant of the within cells correlation matrix was 0.25 , indicating that neither muliticolinearity nor singularity presented a problem in the analysis (Tabachnick and Fidell, 2001).

\section{Results}

With the use of Wilks' criterion, the combined dependent variables were significantly affected by ordering tool usage, $F(9,206)=2.77, p<0.01$, educational tool usage, $F(9,206)=2.25, p<0.05$, and the interaction between ordering tool usage and educational tool usage was also significant, $F(9,206)=2.37$, 


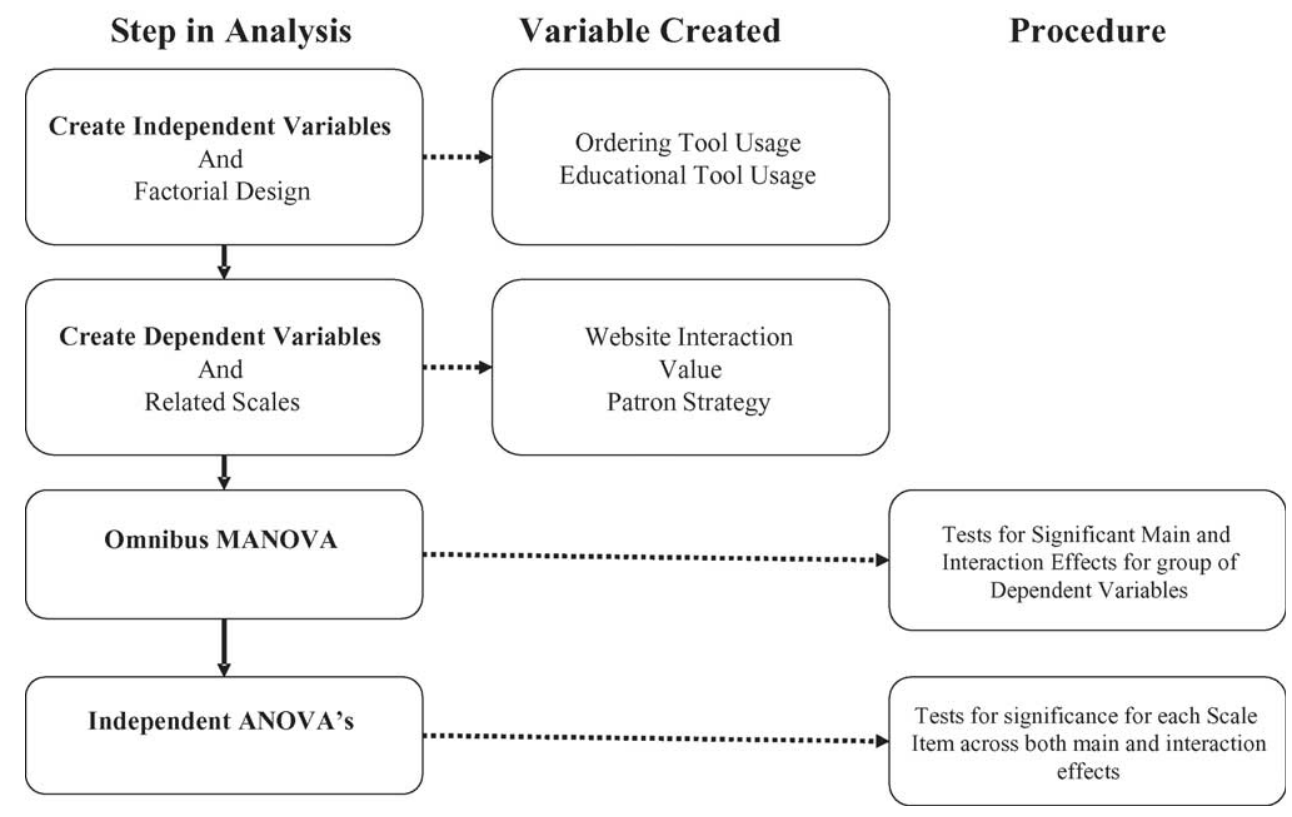

Fig. 3. Research approach.

$p<0.05$. This result supports hypothesis 1 , that is, patron perceptions of overall satisfaction varies across both the economic and mission orientations of the CSO website. Hypotheses $2(\mathrm{a}-\mathrm{c})$ were partially supported each will be discussed in detail in Sections 6.1 and 6.2. Table 2 presents the means, standard deviations, multivariate and univariate $F$-tests for all dependent variables. Since there are only two dimensions for each independent variable, the $F$ ratios associated with Wilk's Lambda, Pillai's Trace and Hotelling Trace will all be the same. We have chosen to only present the Wilks Lambda since it is most common multivariate coefficient.

\subsection{Ordering tools effects}

Significant main effects were found for the ordering tool dimension for the dependent variables of system effectiveness, perspective, overall impression and transactional accuracy. The mean for system effectiveness was significantly larger for high levels of ordering tool use $(M=5.45$, S.D. $=0.96)$ than low ordering tool use $(M=5.10$, S.D. $=0.84)$. The mean for perspective was significantly larger for high levels of ordering tool use $(M=5.77$, S.D. $=0.94)$, than low ordering tool use $(M=5.24$, S.D. $=0.98)$. The mean for impression was significantly larger for high levels of ordering tool use $(M=6.37$, S.D. $=0.94)$ than low ordering tool use $(M=6.06$, S.D. $=1.02)$. Finally the mean for transactional accuracy was significantly larger for high levels of ordering tool use $(M=5.49$, S.D. $=1.25)$ than low ordering tool use $(M=5.03$, S.D. $=1.33$ ).

\subsection{Educational tools effects}

Significant main effects were also found for the educational tool dimension for the dependent variables of system effectiveness and perspective. The mean for system effectiveness was significantly larger for high levels of educational tool use $(M=5.49$, S.D. $=0.87)$ than low educational tool use $(M=5.07$, S.D. $=0.93$ ). Finally, the mean for perspective was significantly larger for high levels of educational tool use $(M=5.76$, S.D. $=0.86)$ than low educational tool use $(M=5.26$, S.D. $=1.05)$.

\subsection{Ordering tools $\times$ educational tool effects}

In viewing the interactions (ordering tools $\times$ educational tools), significant relationships were found for the dependent variables of system effec- 
Table 2

MANOVA

\begin{tabular}{|c|c|c|c|c|c|c|c|c|}
\hline \multirow[t]{4}{*}{ Dependent variables } & & \multicolumn{7}{|c|}{ Independent variables } \\
\hline & & \multicolumn{5}{|c|}{ Tests for main effects } & \multirow{2}{*}{\multicolumn{2}{|c|}{$\begin{array}{l}\text { Test for interaction effect } \\
\text { (ordering } \times \text { educational) }\end{array}$}} \\
\hline & & \multicolumn{2}{|c|}{ Ordering tool usage } & \multicolumn{3}{|c|}{ Educational tool usage } & & \\
\hline & & Wilks Lambda & $F$-test & Wilk & & $F$-test & Wilks Lambda & $F$-test \\
\hline \multicolumn{9}{|l|}{ MANOVA results } \\
\hline & \multicolumn{2}{|r|}{0.93} & $2.21^{*}$ & \multicolumn{2}{|l|}{0.91} & $2.71^{* * *}$ & 0.91 & $2.67^{\text {*** }}$ \\
\hline \multirow[t]{2}{*}{ Scale items } & \multicolumn{3}{|c|}{ Ordering tool usage } & \multicolumn{3}{|c|}{ Educational tool usage } & \multicolumn{2}{|c|}{$($ Ordering $\times$ Educational $)$} \\
\hline & Low & High & $F$-test & Low & High & $F$-test & $F$-test & \\
\hline \multicolumn{9}{|l|}{ ANOVA results } \\
\hline \multicolumn{9}{|c|}{ System effectiveness } \\
\hline Mean & 5.10 & 5.45 & $4.31^{*}$ & 5.07 & 5.49 & $7.17^{* * *}$ & $5.53^{*}$ & \\
\hline S.D. & 0.84 & 0.96 & & 0.93 & 0.87 & & & \\
\hline \multicolumn{9}{|l|}{ Perspective } \\
\hline Mean & 5.24 & 5.77 & $9.69^{* *}$ & 5.26 & 5.76 & $8.05^{* *}$ & 0.66 & \\
\hline S.D. & 0.98 & 0.94 & & 1.05 & 0.86 & & & \\
\hline \multicolumn{9}{|l|}{ Overall impression } \\
\hline Mean & 6.06 & 6.37 & $4.65^{*}$ & 6.16 & 6.28 & 0.05 & 0.13 & \\
\hline S.D. & 1.02 & 0.94 & & 0.96 & 1.00 & & & \\
\hline \multicolumn{9}{|l|}{ Ease of interaction } \\
\hline Mean & 5.82 & 6.07 & 2.23 & 5.82 & 6.08 & 2.16 & 0.30 & \\
\hline S.D. & 0.95 & 0.94 & & 1.04 & 0.84 & & & \\
\hline \multicolumn{9}{|l|}{ Cost } \\
\hline Mean & 3.45 & 3.46 & 0.12 & 3.32 & 3.57 & 1.02 & $3.76^{*}$ & \\
\hline S.D. & 2.01 & 2.01 & & 2.10 & 1.91 & & & \\
\hline \multicolumn{9}{|l|}{ Convenience } \\
\hline Mean & 6.21 & 6.25 & 0.82 & 6.32 & 6.14 & 3.22 & $4.40^{*}$ & \\
\hline S.D. & 0.81 & 0.92 & & 0.79 & 0.93 & & & \\
\hline \multicolumn{9}{|c|}{ Transaction accuracy } \\
\hline Mean & 5.03 & 5.49 & $5.84^{*}$ & 5.15 & 5.36 & 0.19 & 0.24 & \\
\hline S.D. & 1.33 & 1.25 & & 1.33 & 1.28 & & & \\
\hline
\end{tabular}

tiveness, cost and convenience. These relationships are shown in Figs. 4-6. These figures can be interpreted in the following manner. Ordering tools are shown across the bottom axis and progress from low to high. Educational tools are represented by the each line on the graph. The solid line represents low educational tool usage and the dotted represents high educational tool usage. The points where each line intersects with the vertical axes represent the cells for the $2 \times 2$ presented in Fig. 2. Therefore, the point where the solid line intersects with the left hand axis represents the Limited User patrons. The point where the solid line intersects with the right hand axis represents the Functional User patrons. The point where the dotted line intersects with the left hand axis represents the Information Seekers patrons. Finally, the point where the dotted line intersects with the right hand axis represents the Full Service Users patrons. The actual values are the means for each dependent variable scale. The labels for each of the cells of the $2 \times 2$ matrix (Fig. 2) will be used to aid in the discussion of this section. 


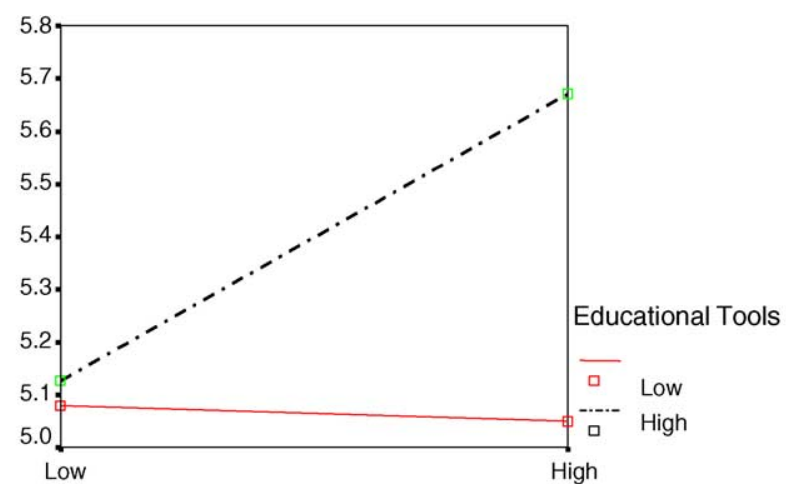

(a) Ordering Tools

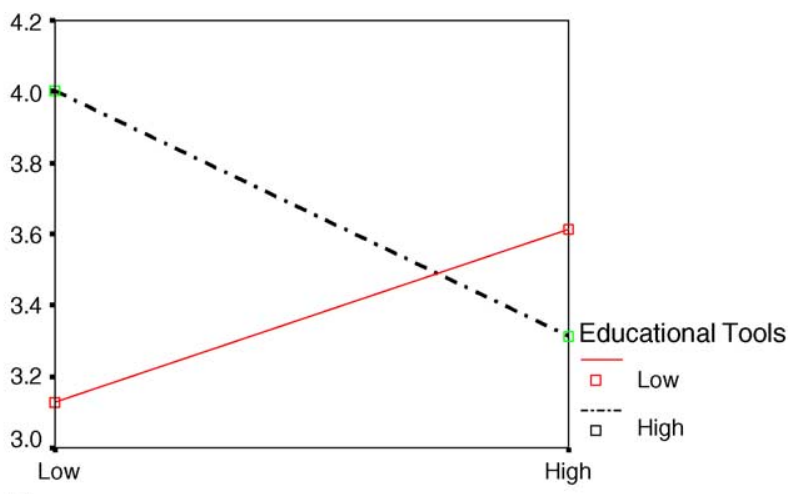

(b) Ordering Tools

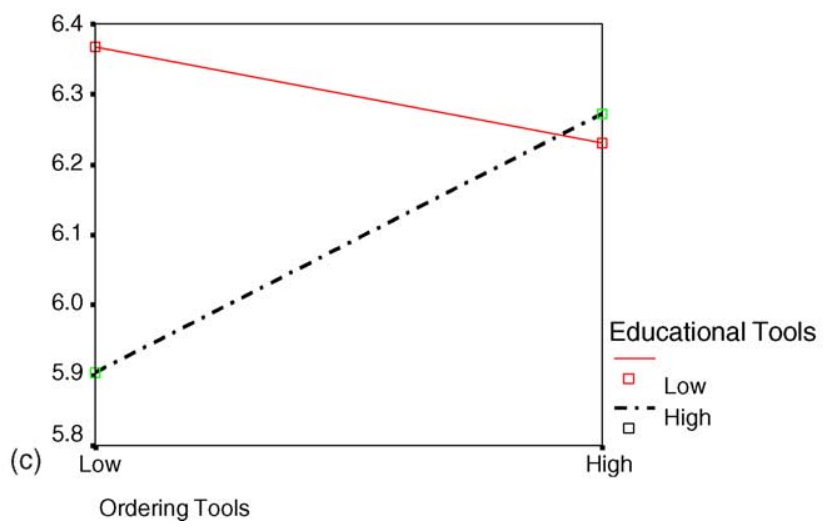

Fig. 4. Marginal means for (a) system effectiveness; (b) cost and (c) convenience.

Fig. 4a depicts the means plot for each of the four patron types for the system effectiveness variable. This plot indicates that the Full Service Users perceive a higher degree of improvement from using the CSO website than the other patron types. Fig. 4b shows the means plot for each of the four patron types for the cost variable. The plot indicates that the Full Service patrons are less likely to have chosen to use the website based on cost than Information Seekers; and Limited User patrons are less likely to have chosen to use the website based on cost than Functional User patrons. Fig. $4 \mathrm{c}$ presents means plot for each of the four patron types for the convenience variable. The plot indicates that the Information Seekers are less likely to have chosen to use the CSO website based on convenience than all other patrons. It is also true that all patrons chose the CSO website as a convenience issue based on their overall mean scores (greater than 6.0).

\section{Discussion}

The results of this study reveal operational and strategic implications for the CSO. The literature from several disciplines identifies two basic aspects or orientations within not-for-profit organizations, economic and mission. The overall MANOVA indicates that patron's have different levels of overall satisfaction with the CSO e-service experience. The tests for main effects indicate that both the economic and educational aspects of the CSO website are important in defining the scope e-service encounter. The interaction effect between ordering and educational tools indicates that patrons have significantly different levels of satisfaction across these dimensions. Although we found an overall significant relationship for both the main and interaction effects, not all of the dependent variables were significantly different. 
Overall the main effect for the ordering tools variable indicated high usage patterns had higher patron ratings on the dependent variables. Independent ANOVAs demonstrated that the variables of system effectiveness, perspective, overall impression and transactional accuracy varied across the ordering tool dimension. Many of the ordering tools are aimed at improving the process related to purchasing tickets; therefore, the overall increase in the scores for the transactional accuracy variable across the ordering tool dimension is expected. In a similar vein, it was also expected that those patrons who were using the various ordering tools would also be higher on both the perspective and impression variables. The intention of the ordering tool features is to assist patrons in making concert and seat selections. That is, these tools allow the patron to interact with the CSO website and choose a concert and seat that best matches their own individual preferences. Since some of the tools are visual, the interaction with the website should be superior to contact with a patron services representative. Thus, it would be expected that patrons would score higher on variables that are related to website interaction.

Likewise, increased use of the educational tools on the website was associated with higher patron ratings on the dependent variables. Logic similar to that of the ordering tool use can be used to explain the main effect of perspective on the educational tool dimension. That is, the overall increase for the perspective would be expected for patrons that use the ordering tools feature on the CSO website. Since the various educational tools include program notes, music samples, and concert information, it was expected that patrons who used the CSO website based on perspective would also chose to use tools that would provide more information on CSO activities.

A significant interaction between the economic and mission orientations was observed in the study which indicates that the economic and mission orientations were operationalized through their patron e-service encounters, although incompletely, at the CSO website. Significant relationships were found for the dependent variables of system effectiveness, cost and convenience. Fig. 4 illustrates that the Full Service Users perceived a greater utility from website interactions than all of the other users. This result is interesting from two perspectives: (1) only the Full
Service Users perceived a greater utility from the website; and (2) the variable is an operation's construct measuring the extent that the website improves a patron's experience with the CSO. This perception is due to the fact that patrons who are using the full range of services on the website are more likely to perceive greater value, increased functionality, because of their intensity of their interaction with the CSO. This perception may also be partially due to gaining familiarity with the website because of greater use, thus, minimizing the amount of time spent on the website.

There are also significant interactions with the cost and convenience variables. The means plots in Fig. 4a would indicate that most patrons do not chose a strategy based on cost. When taking into account the overall mean of the cost variable $(M=$ 3.31, S.D. = 2.02), the Information Seekers had the highest overall mean of the four groups. This result probably occurs because these patrons are budgetminded individuals that are seeking additional information regarding the CSO prior to making a purchase. The means plot for Fig. $4 \mathrm{c}$ would indicate that for the convenience variable, the Limited User, Functional User and Full Service Users were significantly higher than the Information Seekers. One possible explanation is that those who are Information Seekers are exploring the website in greater detail and are less focused on the convenience aspect of the website. Unlike the cost variable we should note that the entire patron list rated convenience very highly. This seems very plausible since customers are able to use the CSO website on their own time and do not have to be concerned with accessing customer services representatives during normal business hours.

While the scales that were found to be significant were important, the remaining scales that did not reach significance were of equal importance: transaction accuracy, perspective, overall impression and ease of interaction. This finding suggests that even though the orientations of the CSO were operationalized through the e-service encounter not all dependent variables had significant interactions. For example, only two of the scales defining the preexisting needs and requirements of the patrons were satisfied. The transactional needs of the patrons were not fully met through the eservice encounter. What was especially noteworthy 
was that all of the subscales for website interaction failed to reach significance. Since these variables are related to the view of the patrons toward the $\mathrm{CSO}$ eservice experience, our expectation was that the scales related to website interaction would have a significant interaction. In summary, the results of this study clearly point out that the CSO, through its e-service encounters, has successfully linked its strategic orientations to its daily interactions with its patrons. Although the overall operational linkages have been generally effective, it should be noted that this study also identifies several areas that can lead to improved performance.

\subsection{Overall impact of e-ticketing on the Chicago Symphony Orchestra}

During the time period from 1998 to 2003, the CSO has continually developed their web based information system. The CSO's website was originally developed as a mechanism to disseminate information on the performances and schedules. Boyer (2000) notes that the customers of the CSO are very demanding and present very detailed questions. The website serves as a means to provide the CSO patrons with relevant information. The original intent of the website was as a vehicle to promote the symphony orchestra; however, ticket selling quickly emerged as a key secondary objective. As demand for on-line ticket purchasing grew, the CSO developed several improved versions of their website.

The second iteration focused on improving the actual sales of concert tickets. Patrons were able to pick the seat and performance they desired and purchase tickets on-line. This version was able to process tickets quickly; however, problems arose in the actual management of the ticket inventory because the information system was not integrated into their overall organizational systems. Consequently, customer service related to the ticketing process suffered. Since the majority of ticket sales were still being processed by call centers, the returns on-line were often not processed in a timely fashion. Thus, seats for many performances were left unfilled because of the duplication of tasks.

Subsequent iterations have focused on integrating the e-ticketing systems with the overall organizational systems. In addition, more content and tools have been made available to patrons on the website. The latest version of the web system (http://www.cso.org) contains an array of ordering related tools to assist patrons in gathering pertinent information so that an informed decision can be made about the purchase of tickets. During the same time period, the CSO also expanded the website to include a diverse set of tools that can access media enhanced content relating to the overall mission of the organization. The CSO' longterm goals are to move all non-season ticket sales to the web based ticketing system. The impact of these continuing improvements to the website has led to a more complete integration of the CSO's economic and mission orientations into its overall organizational processes.

Fig. 5 presents an overview illustrating the CSO's performance in the areas of ticket sales and operational costs. To maintain confidentiality the labor costs are presented as a percentage using 1998 as the base year. The dotted line in Fig. 5 represents the

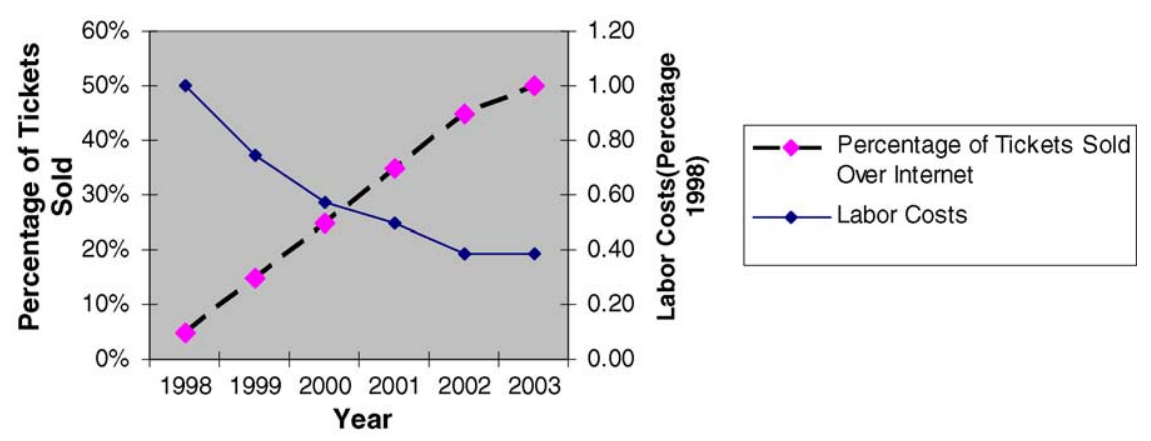

Fig. 5. Impact of e-service based ticket sales. 
percentage of tickets sold through the website. Specifically one sees that the dramatic growth in the revenue generated from the website corresponds with the reduction in the total labor costs associated with ticketing. While other factors also contributed to the overall reduction in labor costs, it is clear that improvements to the CSO website, resulting in increased ticket purchases, was a significant if not predominant contributor to the decline in costs. This relationship leads one to conclude that as the CSO has become more adept at linking its strategic aspects (economic and mission) to their daily operations (website) with the result being that overall operating performance (labor costs and patron satisfaction) has improved.

\section{Appendix A. Final scale items}

\section{A.1. Independent variables}

There are two independent variables in the research model: ordering tools dimension, and educational tools dimension. Each scale consists of questions that measure the degree to which consumers use various items on the CSO website. These items were rated on a 1 (never), 4 (frequently) to 7 (always) Likert scale.

\begin{tabular}{ll}
\hline Scale item & End item questions \\
\hline Ordering tool usage & Event descriptions \\
& Seat selection tool \\
& Concert search tool \\
& Season calendar \\
& E-mail order confirmation \\
& E-mail concert reminder
\end{tabular}

Educational tool usage

Program notes

Music samples

Concert information tool

CSO e-mailing list

Orchestra tour

Musician biographies

CSO rosenthal archives

\section{A.2. Dependent variables}

We have three groups of dependent variables that consist of several scales in the current research study. The larger group of dependent variables is: value, website interaction, and patrons strategy.

\section{A.2.1. Value}

The dependent variable that measures value consists of a single scale that measures systems effectiveness. The scale measures the degree to of improvement when the tasks/events were conducted using the Internet for ordering tickets through the Chicago Symphony Orchestra (CSO) in comparison to traditional methods (order by phone, in-person, fax or mail. These items were rated on a 1 (large decrease), to 7 (larger increase) Likert scale.

\begin{tabular}{ll}
\hline Scale item & End item questions \\
\hline System & The time to place an order \\
effectiveness & The delivery time from when \\
& an order is placed to receipt of \\
all items & The thoroughness of order \\
& documentation \\
& The ease of interpretation for \\
documentation & The reliability of delivery \\
\hline
\end{tabular}

\section{A.2.2. Website interaction}

The dependent variable that measures website interaction consists of a three scales that measures perceptions of how patrons interact with the CSO. The three scales used to measure this variable are: perspective, overall impression, and ease of interaction. These items were rated on a 1 (large decrease), to 7 (larger increase) Likert scale.

\begin{tabular}{ll}
\hline Scale item & End item questions \\
\hline Perspective & I like using Internet ordering \\
& Internet ordering is fun to use \\
& Internet ordering provides an \\
& attractive ordering method. \\
& One of my favorite leisure \\
activities is exploring the Internet
\end{tabular}




$\begin{array}{cl}\begin{array}{c}\text { Overall } \\ \text { impression }\end{array} & \begin{array}{l}\text { Ordering tickets online is } \\ \text { more attractive than other } \\ \text { ordering methods } \\ \text { I will use the CSO site } \\ \text { in the future }\end{array} \\ \text { Ease of } & \begin{array}{l}\text { It is easy for me to } \\ \text { remember how to perform } \\ \text { tasks using Internet ordering } \\ \text { It is easy to get Internet ordering } \\ \text { to do what I want it to do } \\ \text { My interaction with Internet } \\ \text { ordering is clear and } \\ \text { understandable } \\ \text { Overall, I believe that Internet } \\ \text { ordering is easy to use }\end{array} \\ \end{array}$

\section{A.2.3. Patron strategy}

The dependent variable that measures patron strategy consists of a three scales that measures the importance of various factors to choosing the CSO. The three scales used to measure this variable are: cost, convenience, and transactional accuracy. These items were rated on a 1 (not important), to 7 (very important) Likert scale.

\begin{tabular}{ll}
\hline Scale item & End item questions \\
\hline Cost & Cost \\
Convenience & Convenience \\
& Delivery speed \\
& Faster access to ticket \\
& information \\
& Ordering speed \\
Transactional & Order accuracy \\
accuracy & Customer service of system \\
& Security of system \\
\hline
\end{tabular}

\section{References}

Anheier, H.K., Ben-Ner, A., 1997. Shifting boundaries: long-term changes in the size of the for-profit, nonprofit, cooperative and government sectors. Annals of Public and Cooperative Economics 68 (3), 335-353.
Anheier, H.K., Rudney, G., 1998. An input-output analysis of the nonprofit sector in the USA and Germany. Annals of Public and Cooperative Economics 69 (1), 5-31.

Balasubramanian, S., Prabhudev, P., Menon, N., 2003. Customer satisfaction in virtual environments: a study on on-line investing. Management Science 49 (7), 871-889.

Ben-Ner, A., van Hoomissen, T., 1991. Nonprofit organizations in a mixed economy: a demand supply analysis. Annals of Public and Cooperative Economics 68 (3), 335-353.

Becker, G., 1965. A theory of the allocation of time. Economic Journal 75, 493-517.

Boyer, K.K., 2001. E-operations: a guide to streamlining with the Internet. Business Horizons 44 (1), 47-54.

Boyer, K.K., Olson, J.R., 2002. Drivers of Internet purchasing success. Production and Operations Management 11 (4), 480498.

Bryson, J.M., Gibbons, M.J., Shaye, G., 2001. Enterprise schemes for nonprofit survival, growth, and effectiveness. Nonprofit Management \& Leadership 11 (3), 271-288.

Burt, E., Taylor, J.A., 2000. Information and communication technologies: reshaping voluntary organizations? Nonprofit Management \& Leadership 11 (2), 131-143.

Colkin, E., 2001. Website overhaul is music to patrons' ears. Information Week 831, 88-89.

Davis, F., Bagozzi, R., Warshaw, 1989. User acceptance of computer technology: a comparison of two theoretical models. Management Science 35 (8), 982-1003.

Dees, J.G., 1998. Enterprising nonprofits. Harvard Business Review 76 (1), 55-67.

Devaraj, S., Fan, M., Kohli, R., 2002. Antecedents of B2C channel satisfaction and preference: validating e-commerce metrics. Information Systems Research 13 (3), 317-333.

Durst, S., Newell, C., 2001. The who, why, and how of reinvention in nonprofit organizations. Nonprofit Management \& Leadership 11 (4), 443-457.

Ekelund, R., Ritenour, S., 1999. The exploration of the Beckerian theory of time costs: symphony concert demand. The American Journal of Economics and Sociology 58 (4), 887-899.

Froehle, C.M., Roth, A.V., Chase, R.B., Voss, C.A., 2000. Antecedents of new service development effectiveness: an exploratory examination of strategic operations choices. Journal of Service Research 3 (1), 3-17.

Frohlich, M., 2002. Techniques for improving response rates in OM survey research. Journal of Operations Management 20 (4), 5362.

Iqbal, Z., Verma, R., Baran, R., 2003. Understanding consumer choices and preferences in transaction based e-services. Journal of Service Research 6 (1), 51-65.

Konana, P., Balasubramanian, S., 2004. The social-economic-psychological model of technology adoption and usage: an application to online investing. Decision Support Systems, in press.

Lynch Jr., G., Ariely, D., 2000. Wine online: search costs affect competition on price, quality, and distribution. Marketing Science 19 (1), 83-102.

Mechling, G., Little, B., 2000. Service encounter mismatches: a conceptual framework integrating it and job design. Journal of Business Strategies 17 (1), 65-85. 
Murphy, J., Hofacker, C.F., Bennett, M., 2001. Website generated market research data: tracing the tracks left behind by visitors. Cornell Hotel \& Restaurant Administration Quarterly 42 (1), 82-91.

National Endowment for the Arts (NEA), 2004. National Endowment for the Arts Appropriations History. http://www.nea.gov/ about/Facts/AppropriationsHistory.html. 28 March 2004.

Palvia, P.C., Palvia, S.C., 1999. An examination of the IT satisfaction of small-business users. Information \& Management 35, 127-137.

Quarter, J., Richmond, B.J., 2001. Accounting for social value in nonprofits and for-profits. Nonprofit Management \& Leadership 12 (1), 75-85

Reimenschneider, C.K., Harrison, D.A., Mykytyn Jr., P.P., 2003. Understanding IT adoption decisions in small business: integrating current theories. Information \& Management 40, 269-285.

Rojas, R.R., 2000. A review of models for measuring organizational effectiveness among for-profit and nonprofit organizations. Nonprofit Management \& Leadership 11 (1), 97-104.

Ryan, W.P., 1999. The new landscape for nonprofits. Harvard Business Review 77 (1), 127-136.
Saidel, J.R., Cour, S., 2003. Information technology and the voluntary sector workplace. Nonprofit and Voluntary Sector Quarterly 32 (1), 5-24.

Salamon, L.M., 1994. The rise of the nonprofit sector. Foreign Affairs 73 (4), 109-122.

Salamon, L.M., 1996. The crisis of the nonprofit sector and the challenge of renewal. National Civic Review 85 (4), 3-16.

Tabachnick, B.G., Fidell, L.S., 2001. Using Multivariate Statistics, fourth ed. Allyn and Bacon, Boston, MA.

Torkzadeh, G., Dhillon, G., 2002. Measuring factors that influence the success of Internet commerce. Information Systems Research 13 (2), 187-204.

Zeithaml, V., Berry, L., Parasuraman, A., 1988. Communication and control processes in the delivery of service quality. Journal of Marketing 52 (4), 35-48.

Zeithaml, V.A., Parasuraman, A., Malhotra, A., 2000. A conceptual framework for understanding e-service quality: implications for future research and managerial practice. Marketing Science Institute Report No. 00-115.

Vence, D., 2003. Boston orchestra tunes up net campaign. Marketing News 37 (13), 5-6. 